\title{
HUBUNGAN TEKSTUR SEDIMEN DAN BAHAN ORGANIK DENGAN MAKROZOOBENTOS DI HABITAT MANGROVE PANTAI TIRANG SEMARANG
}

\author{
The Relationship between Sediment Textures and Organic Materials with Macrozoobenthos \\ in Mangrove Habitat at Tirang Beach Semarang
}

Hiskia Arapenta Sinulingga, Max Rudolf Muskananfola*) dan Siti Rudiyanti

Program Studi Manajemen Sumberdaya Perairan, Departemen Sumberdaya Akuatik

Fakultas Perikanan dan Ilmu kelautan, Universitas Diponegoro

Jl. Prof. Soedarto, SH, Tembalang, Semarang, Jawa Tengah - 50275. Telp/Fax. +6224 7474698

Email: k.arapenta@gmail.com

\begin{abstract}
ABSTRAK
Pantai Tirang merupakan salah satu pantai di Semarang, terletak di sebelah barat dari bandara Ahmad Yani, pantai Maron dan Muara Kali Angke di Desa Tambakrejo, Kecamatan Tugu, Kabupaten Semarang. Tujuan dari penelitian ini adalah untuk mengetahui tekstur sedimen dan bahan organik, mengetahui nilai indeks biologi (indeks keanekaragaman, indeks keseragaman, dan indeks dominasi), dan mengetahui hubungan tekstur sedimen dan bahan organik dengan makrozoobentos di Habitat Mangrove Pantai Tirang Semarang. Metode yang digunakan dalam penelitian ini adalah: metode deskriptif (analisa lapangan dan laboratorium). Analisa lapangan di Pantai Tirang Semarang dan analisa laboratorium di Lab Pengelolaan Sumberdaya Ikan dan Lingkungan Fakultas Perikanan dan Ilmu Kelautan Universitas Diponegoro. Pengambilan sampel dilakukan 3 kali dengan interval waktu 2 minggu sekali. Hasil penelitian menunjukkan bahwa tektur sedimen didominasi oleh fraksi pasir berkisar 90,92-94,56\% pada sampling pertama; fraksi liat 26,08 - 61,24\% pada sampling kedua; fraksi liat berkisar 23,28-59,88\% pada sampling ketiga; dan Nilai bahan organik berkisar antara 1,88-5,88\%. Nilai indeks keanekaragaman berkisar 0,563-1,003, indeks keseragaman berkisar 0,579-0,909, indeks dominasi berkisar 0,371-0,624 dan kelimpahan makrozoobentos berkisar antara 1995,27-5985,83 ind $/ \mathrm{m}^{3}$. Jenis makrozoobentos yang mendominasi adalah dari genus Cerithidea. Hubungan tekstur sedimen dominan (fraksi clay) dan bahan organik dengan makrozoobentos: fraksi clay dengan kelimpahan makrozoobentos memiliki hubungan terbalik, semakin tinggi fraksi clay maka kelimpahan makrozoobentos makin rendah dengan koefisien korelasi -0,18. Bahan organik dengan kelimpahan makrozoobentos memiliki keeratan hubungan sedang, bahan organik makin tinggi maka kelimpahan makrozoobentos meningkat.
\end{abstract}

Kata Kunci : Tekstur Sedimen; bahan organik; makrozoobentos; Pantai Tirang Semarang

\section{ABSTRACT}

Tirang Beach is one of the beaches in Semarang located at the westside of Ahmad Yani airport, Maron Beach and the estuari of Angke River, Tambakrejo village, Tugu subdistrict, Semarang Regency. The objective of the research is to determine the sediment textures and organic matters, to know the biological indices (diversity index, uniformity index, and the dominance index), and to determine the relationship between macrozoobenthos with sediment textures and organic matter in Mangrove habitat at Tirang Beach Semarang.This study adopts a descriptive method (Field and laboratory analysis). Field analysis in Tirang Beach Semarang and laboratory analysis at the Laboratory of Fish Resources Management and Environment Faculty of Fisheries and Marine Sciences, University of Diponegoro in Semarang. Sampling was conducted three times at intervals of 2 weeks. The results of this study shows that sediment textures is dominated by sand fraction ranged from 90,92 to 94,56\% at fiirst sampling; clay fractions ranged from 26,08 to 61,24\% at second sampling; clay fraction ranged from 23,28-59,88\% at third sampling. Diversity index values ranged from 0,563 to 1,003, uniformity index ranges from 0,579 to 0,909, dominance index ranged from 0,371 to 0,624 and the abundance of macrozoobenthos from 1995.27 to $5985.83 \mathrm{ind} / \mathrm{cm}^{3}$. Macrozoobenthos is dominated by genus Cerithidea. Relation of sediment texture (clay fraction) and organic material with macrozoobenthos. The clay fraction and abundance of macrozoobenthos has a negative correlation, high clay concentration low macrozoobenths abundance and correlation value of -0.18. Organic matter and abundance of macrozoobenthos has a moderate correlation, high organic material high macrozoobenthos abundance and correlation value 0.73.

Keywords: Sediment textures, organic matters; Macrozoobenthos; Tirang Beach Semarang 


\section{PENDAHULUAN}

Pantai Tirang terletak di daerah barat Kota Semarang tepatnya di sebelah muara Kali Silandak. Menuju ke Pantai Tirang dapat melalui dua jalan yaitu dari pintu gerbang Bandara Ahmad Yani dan Perumahan Graha Padma. Pantai Tirang berjarak 4,2 km dari Bundaran Kalibanteng Semarang. Pantai Tirang banyak hutan mangrove selain memiliki hutan mangrove pantai tirang juga banyak terdapat tambak ikan dan tambak udang.

Sedimen adalah partikel organik dan anorganik yang terakumulasi secara bebas (Duxbury et al, 1991dalam Mukminin, A, 2009). Suatu endapan sedimen disusun dari berbagai ukuran partikel sedimen yang berasal dari sumber yang berbeda-beda, dan percampuran ukuran ini disebut dengan istilah POPULASI. Pergerakan udara dan air dapat memisahkan partikel berdasarkan ukuran mereka, menyebabkan endapan terdiri dari berbagai ukuran. Ada tiga kelompok populasi sedimen yaitu: 1) Gravel (kerikil), terdiri dari partikel individual: boulder, cobble dan pebble; 2) Sand (pasir), terdiri dari: pasir sangat kasar, kasar, medium, halus dan sangat halus; 3) Mud (lumpur), terdiri dari clay dan silt.

Bahan Organik Total (BOT) menggambarkan kandungan bahan organik total suatu perairan yang terdiri dari bahan organik terlarut, tersuspensi (partikulate) dan koloid. Bahan organik ditemukan dalam semua jenis perairan, baik dalam bentuk terlarut, tersuspensi maupun sebagai koloid, dimana kesuburan suatu perairan tergantung dari kandungan Bahan Organik Total (BOT) dalam perairan itu sendiri.

Kandungan bahan organik total yang mudah larut dalam air berkisar antara 0,3-3 mg C/1, walaupun berbeda dengan yang ditemukan di perairan pantai akibat aktivitas plankton dan polusi dari daratan (20 mg C/l). Bagian utama dari kandungan bahan organik terlarut terdiri dari materi kompleks yang sangat tahan terhadap bakteri, tetapi secara ekologis merupakan bagian penyusun kecil campuran yang labil tetapi sangat penting (Baslim, 2001 dalam Mardi, 2014).

Organisme bentos adalah organisme yang mendiami dasar perairan atau tinggal didalam sedimen dasar. Organisme bentos meliputi organism nabati yang disebut fitobentos dan organisme hewani disebut zoobentos (Odum, 1971 dalam Syamsurisal, 2011). Berdasarkan ukurannya maka organisme bentos dibedakan menjadi dua kelompok besar, yaitu makrozoobentos dan mikrozoobentos. Makrozoobentos adalah organism yang tersaring oleh saringan bertingkat dengan ukuran 0,5 mm (Lind,1979 dalam Ihklas, 2001) sedangkan Hutabarat dan Evans (2000) mengklasifikasikan zoobentos menjadi tiga kelompok yaitu mikrofauna yang ukurannya lebih kecil dari $0,1 \mathrm{~mm}$, meiofauna yang berukuran antara 0,1 $\mathrm{mm}$ dan makrofauna yang ukurannya lebih besar dari 1,0 $\mathrm{mm}$.

Tujuan dari penelitian ini adalah sebagai berikut: 1) Mengetahui tekstur sedimen dan bahan organik; 2) Mengetahui indeks biologis dari makrozoobentos; dan 3) Mengetahui hubungan tekstur sedimen dan bahan organik dengan makrozoobentos di Habitat Mangrove Pantai Tirang Semarang.

\section{MATERI DAN METODE PENELITIAN}

Lokasi penelitian dilakukan di Pantai Tirang Semarang. Pemilihan lokasi penelitian setelah melakukan survei ke Pantai Tirang. Metode yang digunakan dalam penelitian ini adalah purposive sampling method. Purposive sampling method adalah metode yang mengambil beberapa sampel secara acak yang mewakili seluruh Pantai Tirang.

\section{Analisis Lapangan}

Mengambil data berupa parameter fisika dan kimia di lapangan. Parameter fisika dan kimia meliputi kecepatan arus, suhu udara, suhu air, kedalaman, kecerahan, salinitas, dan pH. Mengambil sampel sedimen dan makrozoobentos di Pantai Tirang untuk selanjutnya diamati di Lab. Pengelolaan Sumberdaya Ikan dan Lingkungan Fakultas Perikanan dan Ilmu Kelautan Universitas Diponegoro.

\section{Analisis Laboratorium}

\section{Tekstur sedimen}

Sampel sedimen dimasukkan kedalam oven untuk mengeringkan air yang masih ada di dalam sedimen. Mengeringkan sedimen butuh waktu satu harian. Setelah kering sampel sedimen selanjutnya dilakukan 2 metode.

- Metode sieve shaker

Mengambil 50 gram sampel sedimen yang telah kering. Masukan 50 gram sampel sedimen kedalam seive shaker. Nyalakan sieve shaker selama 15 menit. Setelah 15 menit matikan sieve shaker. Keluarkan sampel sedimen di sieve net. Timbang sedimen yang ada di setiap sieve net.

- Metode pemipetan (Buchanan)

Mengambil 25 gram sampel sedimen. Menuangkan 25 gram sedimen ke sieve net. Sedimen di sieve net tuangkan air secara pelan pelan sambil diaduk sedimen dengan kuas. Air sedimen masukan kedalam gelas ukur yang berukuran 1000 ml. Diamkan sedimen selama 1 malam agar sedimen mengendap. Sebelum melakukan pemipetan, gelas ukur ditutup dengan plastik wrap. Agas tidak tumpah saat penggojokan. Gojok gelas ukur agar tidak ada sedimen yang menimbun di bawah permukaan gelas ukur. Hasil pemipetan masukan ke gelas ukur. Gelas ukur hasil pemipetan di oven. Setelah di oven timbang gelas ukur tersebut. 


\section{Bahan organik}

Menimbang 25 gram sampel sedimen. Masukan sampel sedimen kedalam furnace. Diamkan furnace selama 5-6 jam dengan suhu 500 ${ }^{\circ} \mathrm{C}$. Setelah 5-6 jam dinginkan sedimen di dalam furnace. Setelah dingin ambil sampel sedimen dan timbang sedimen setelah furnace.

\section{Makrozoobentos}

Menuangkan sampel makrozoobentos ke cawan petri dish. Mengamati makrozoobentos dengan lup. Mencocokan makrozoobentos dengan buku referensi. Buku referensi yang digunakan buku FAO.

\section{Analisis Data}

Dalam penelitian banyak menggunakan rumus-rumus antara lain:

\section{Tekstur Sedimen}

- Metode Pemipetan Buchanan (1971) rumus:

a. Sand $=(N 1+N 2+N 3+N 4+N 5)$

Fraksi sand $=\frac{\text { Berat total }(\text { gram })}{25 \text { gram }} \times 100 \%$

b. Silt $(\operatorname{gram})=(N 1-N 2)+(N 2-N 3)+(N 3-N 4)+(N 4-N 5)$

Silt $($ gram $)=\frac{1000 \mathrm{ml}}{20 \mathrm{ml}} x$ berat silt $($ gram $)$

Fraksi slit $=\frac{\text { Berat total }(\text { gram })}{25 \text { gram }} \times 100 \%$

c. Fraksi clay $=100 \%-\%$ sand $-\%$ silt

- Metode Sieve Shaker

$$
\% \text { Berat }=\frac{\text { Berat Hasil Ayakan }}{\text { Berat Awal }(\text { gram })} \times 100 \%
$$

\section{Bahan Organik}

Keterangan:

$$
\begin{gathered}
\text { Berat BOT }=(B C K+B S)-B S P \\
\% \text { Bahan Organik }=\frac{\text { Berat BOT }}{\text { Berat Sampel }} \times 100 \%
\end{gathered}
$$

$\mathrm{BCK}=$ Berat Cawan Kosong ( gram)

$\mathrm{BS}=$ Berat Sampel ( gram)

$\mathrm{BSP}=$ Berat Setelah Pijar $($ gram $)$

\section{Makrozoobentos}

- Indeks Keanekaragaman (H')

Indeks keanekaragaman organisme makrozoobenthos dihitung dengan menggunakan rumus Shannon-Wiener (Odum 1971):

Keterangan:

$$
H^{\prime}=-\sum_{i=1}^{s} p i \operatorname{lnpi}
$$

$\mathrm{H}^{\prime}=$ Indeks keanekaragaman jenis

$\mathrm{s}=$ Jumlah yang menyusun komunitas

pi =Rasio jumlah individu spesies ke-I (ni) dengan jumlah individu dalam komunitas (N)

Kriteria yang digunakan untuk menggambarkan keanekaragaman Shannon-Wiener yaitu :

- $\mathrm{H}^{\prime}=<1$, keanekaragaman rendah

$-\mathrm{H}^{`}=1-3$, keanekaragaman tergolong sedang

- $\mathrm{H}^{\prime}=>3$, keanekaragaman tergolong tinggi

- Indeks Keseragaman (e)

Indeks keseragaman organisme makrozoobentos dihitung dengan menggunakan rumus Evennes Indeks (Odum 1971):

$$
e=\frac{H^{\prime}}{H \max }
$$


Keterangan:

$\mathrm{e}=$ Indeks keseragaman

$\mathrm{H}^{\prime}=$ Indeks keanekaragaman

$\mathrm{Hmax}=\ln \mathrm{S}$

Nilai indeks keseragaman berkisar antara 0-1. Apabila nilai e $<0,20$ dapat dikatakan kondisi penyebaran jenis tidak merata, sedangkan apabila nilai e 0,21<e $<1$ dapat dikatakan kondisi penyebaran jenis merata (Krebs, 1986).

- Indeks Dominasi (C)

Indeks dominansi organisme makrozoobenthos dihitung dengan menggunakan rumus Odum (1971) :

Keterangan:

$$
C=\sum\left(\frac{n i}{N}\right)^{2}
$$

$\mathrm{C}=$ Indeks dominasi

$\mathrm{N}=$ Jumlah individu seluruh spesies

ni = Jumlah individu spesies ke-i

Dengan kriteria :

Apabila nilai $\mathrm{C}$ mendekati 0 (nol) $=$ Tidak ada jenis yang mendominasi

Apabila nilai $\mathrm{C}$ mendekati $1(\mathrm{satu})=$ Ada jenis yang mendominasi

- Kelimpahan individu (D)

Kelimpahan adalah banyaknya jumlah individu dan jumlah jenis yang ditemukan pada luas daerah pengamatan.

Kelimpahan dapat dihitung dengan menggunakan rumus (Odum 1994):

Keterangan :

$$
D=\frac{1000000}{V} \times \sum \mathrm{Ni}
$$

$\mathrm{D}=$ Kelimpahan $/$ Kepadatan $\left(\mathrm{Ind} / \mathrm{m}^{3}\right)$

$\mathrm{Ni}=$ Jumlah Individu (Ind)

$\mathrm{V}=$ volume wilayah pengambilan data $\left(\mathrm{m}^{3}\right)$

$1000.000=$ konversi

Analisis Data menggunakan analisis regresi linier sederhana dan analisis korelasi di Microsoft Excel

\section{III.HASIL DAN PEMBAHASAN}

Pantai Tirang adalah pantai yang baru dikenal di Semarang. Pantai Tirang berada di ujung landasan pacuan Bandara Ahmad Yani dan sebelah barat Pantai Maroon. Pantai Tirang memiliki habitat mangrove yang luas.

\section{PARAMETER FISIKA DAN KIMIA PERAIRAN}

Hasil parameter fisika dan kimia perairan di Habitat Mangrove Pantai Tirang dapat dilihat pada tabel 1

\begin{tabular}{|c|c|c|c|c|c|c|c|c|c|}
\hline \multirow{2}{*}{$\begin{array}{c}\text { Parameter } \\
\text { Fisika/ Kimia }\end{array}$} & \multicolumn{3}{|c|}{ Sampling 1} & \multicolumn{3}{|c|}{ Sampling 2} & \multicolumn{3}{|c|}{ Sampling 3} \\
\hline & I & II & III & $\mathbf{I}$ & II & III & I & II & III \\
\hline Suhu udara & & & & & & & & & \\
\hline$\left({ }^{0} \mathrm{C}\right)$ & 31 & 30 & 32 & 31 & 34 & 34 & 31 & 32 & 32 \\
\hline Suhu air $\left({ }^{0} \mathrm{C}\right)$ & 34 & 35 & 34 & 30 & 36 & 39 & 33 & 30 & 30 \\
\hline $\begin{array}{l}\text { Kedalaman } \\
(\mathrm{cm})\end{array}$ & 64 & 24 & 55 & 82 & 35 & 26 & 90 & 40 & 43 \\
\hline $\begin{array}{l}\text { Kecerahan } \\
(\mathrm{cm}) \\
\text { Kecepatan }\end{array}$ & 37 & $\sim$ & 32,5 & 33 & $\sim$ & $\sim$ & 31,5 & $\sim$ & $\sim$ \\
\hline $\operatorname{Arus}(\mathrm{m} / \mathrm{s})$ & $\sim$ & 0,02 & 0,016 & $\sim$ & $\sim$ & $\sim$ & 0,01 & $\sim$ & 0,018 \\
\hline $\mathrm{pH}$ & 6 & 8 & 8 & 7 & 8 & 8 & 7 & 8 & 8 \\
\hline Salinitas (\%o) & 27 & 27 & 27 & 30 & 28 & 28 & 27 & 25 & 27 \\
\hline
\end{tabular}
Tabel 1. Parameter fisika dan kimia perairan

Bedasarkan hasil penelitian di Habitat Mangrove Pantai Tirang Semarang didapatkan suhu udara berkisar antara 3032 0C pada sampling pertama, 31-34 0C pada sampling kedua, dan 31-32 0C pada sampling ketiga. Suhu air berkisar antara 34-35 0C pada sampling pertama, 30-39 0C pada sampling kedua, dan 30-33 0C pada sampling ketiga. Menurut Rahman (2009), suhu optimum bagi perkembangan makrobenthos berkisar antara $20-30{ }^{\circ} \mathrm{C}$, pada kisaran suhu yang tinggi sekitar $33-50{ }^{\circ} \mathrm{C}$ menyebabkan terjadinya gangguan perkembangan daur hidup, dan penurunan suhu dapat menyebabkan perpanjangan waktu pergantian generasi. Menurut Effendi (2003), organisme akuatik memiliki kisaran suhu tertentu yang disukai bagi pertumbuhannya. Peningkatan suhu juga dapat menyebabkan peningkatan kecepatan metabolisme dan respirasi organisme air yang selanjutnya menyebabkan peningkatan konsumsi oksigen. 
Kedalaman selama sampling sangat beragam. Pada sampling pertama kedalaman berkisar antara 24-64 cm. Sampling kedua berkisar antara 26-82 cm dan sampling ketiga berkisar antara 40-90 cm. Menurut Zahidin (2008), kedalaman suatu perairan akan berpengaruh terhadap jumlah dan jenis hewan makrobenthos, dimana kedalaman berpengaruh terhadap kelimpahan serta distribusi hewan makrobenthos. Perairan dengan kedalaman berbeda akan dihuni oleh makrobenthos yang berbeda pula dan terjadi komunitas yang berbeda.

Nilai $\mathrm{pH}$ : sampling pertama berkisar antara 8-8, sampling kedua berkisar antara 7-8 dan sampling ketiga berkisar antara 7-8. Menurut Effendi (2003), bahwa sebagian besar biota akuatik akan sensitif jika terdapat perubahan $\mathrm{pH}$, sedangkan kisaran $\mathrm{pH}$ yang disukai sekitar 7 - 8,5 apabila nilia $\mathrm{pH}$ 6,0-6,5 dapat menyebabakan keanekaragaman makrobenthos akan menurun. Menurut Odum (1993), pada $\mathrm{pH}$ yang optimum organisme yang hidup didalamnya akan bertahan, sebaliknya jika pH perairan terlalu tinggi atau terlalu rendah akan mempengaruhi ketahanan hidup organisme didalamnya.

Salinitas yang diperoleh dalam penelitian adalah sebagai berikut: sampling pertama $27 \%$, sampling kedua berkisar antara $28-30 \%$ dan sampling ketiga berkisar antara $25-27 \%$.

\section{Tekstur Sedimen}

Hasil tekstur sedimen di Habitat Mangrove Pantai Tirang dapat dilihat pada tabel 2.

Tabel 2. Persentasi tekstur sedimen (sand, clay dan silt)

\begin{tabular}{clcccc}
\hline Sampling & Stasiun & $\begin{array}{c}\text { sand } \\
\text { (\%) }\end{array}$ & $\begin{array}{c}\text { Silt } \\
(\mathbf{\%})\end{array}$ & $\begin{array}{c}\text { clay } \\
\mathbf{( \% )}\end{array}$ & $\begin{array}{c}\text { Jenis } \\
\text { Tekstur Sedimen }\end{array}$ \\
\hline \multirow{2}{*}{1} & I & 91,86 & 6,12 & 2,02 & Pasir \\
& II & 94,56 & 3,54 & 1,9 & Pasir \\
& III & 90,92 & 3,72 & 5,36 & Pasir \\
2 & I & 2,76 & 36 & 61,24 & Liat \\
& II & 5,92 & 68 & 26,08 & Lempung berdebu \\
& III & 3,44 & 46 & 50,56 & Liat berdebu \\
3 & I & 10,12 & 30 & 59,88 & Liat \\
& II & 10,72 & 66 & 23,28 & Lempung berdebu \\
& III & 8,52 & 36 & 55,48 & Liat \\
\hline
\end{tabular}

Sedimen di Habitat Mangrove Pantai Tirang mendominasi sand dan clay. Sand berkisar 90,92-94,56 \% pada sampling pertama. Clay berkisar antara 26,08-61,24 \% pada sampling kedua dan berkisar antara 23,28-59,88 \% pada sampling ketiga. Substrat lumpur dan pasir merupakan habitat yang paling disukai makrozoobentos, selanjutnya Lind (1979) dalam Ihklas (2001) menyatakan bahwa hewan bentos lebih menyenangi dasar perairan dengan substrat lumpur, pasir, kerikil dan substrat sampah.

\section{Bahan Organik}

Hasil bahan organik di Habitat Mangrove Pantai Tirang dapat dilihat pada tabel 3.

Tabel 3. Persentasi bahan organik di Habitat Mangrove Pantai Tirang

\begin{tabular}{|c|c|c|}
\hline Sampling & Stasiun & $\begin{array}{c}\text { BOT } \\
(\%)\end{array}$ \\
\hline \multirow{3}{*}{1} & I & 2,32 \\
\hline & II & 2,84 \\
\hline & III & 3,96 \\
\hline \multirow{3}{*}{2} & I & 4,24 \\
\hline & II & 3,6 \\
\hline & III & 2,92 \\
\hline \multirow{3}{*}{3} & I & 1,88 \\
\hline & II & 2,2 \\
\hline & III & 5,88 \\
\hline
\end{tabular}

Kandungan bahan organik di Habitat Mangrove Pantai Tirang berkisar antara 2,32-3,96 \% pada sampling pertama, 2,92-4,24 \% pada sampling kedua dan 1,88-588 \% pada sampling ketiga. Menurut Faizal (2011), tingginya bahan organik yang masuk keperairan berasal dari peningkatan aktivitas didaratan seperti pemupukan disawah dan tambak, budidaya, industri dan aktivitas rumah tangga yang masuk kedalam perairan. Menurut Nybakken (1992), bahwa muara sungai sangat kaya akan bahan organik yang disebabkan partikel yang mengendap di air laut maupun air tawar pada umumnya mengandung bahan organik.

\section{Makrozoobentos}

Hasil nilai indeks biologi (indeks keanekaragaman, keseragaman dan dominasi dapat dilihat pada tabel 4 
Tabel 4. Nilai indeks biologi (indeks keanekaragaman, keseragaman dan dominasi) makrozoobentos di Habitat Mangrove Pantai Tirang

\begin{tabular}{|c|c|c|c|c|c|}
\hline Sampling & Stasiun & $\begin{array}{c}\text { Indeks } \\
\text { Keanekaragaman } \\
\left(H^{\prime}\right)\end{array}$ & $\begin{array}{c}\text { Indeks } \\
\text { Keseragaman } \\
\text { (e) }\end{array}$ & $\begin{array}{c}\text { Indeks } \\
\text { Dominasi } \\
\text { (C) }\end{array}$ & $\begin{array}{c}\text { Kelimpahan } \\
\text { Individu } \\
\text { (D) individu } / \mathrm{m}^{3}\end{array}$ \\
\hline \multirow{3}{*}{1} & I & 0,808 & 0,735 & 0,499 & 5415,75 \\
\hline & II & 0,579 & 0,836 & 0,607 & 4275,59 \\
\hline & III & 0,563 & 0,81 & 0,624 & 4560,63 \\
\hline \multirow{3}{*}{2} & I & 0,828 & 0,753 & 0,486 & 5130,71 \\
\hline & II & 0,985 & 0,895 & 0,413 & 4560,63 \\
\hline & III & 0,687 & 0,625 & 0,619 & 3705,51 \\
\hline \multirow{3}{*}{3} & I & 1,003 & 0,892 & 0,371 & 1995,27 \\
\hline & II & 0,636 & 0,579 & 0,554 & 3420,47 \\
\hline & III & 0,999 & 0,909 & 0,391 & 5985,83 \\
\hline
\end{tabular}

Nilai indeks biologi di Habitat Mangrove Pantai Tirang adalah sebagai berikut: Nilai indeks keanekaragaman berkisar antara 0,563-0,808 pada sampling pertama, 0,687-0,985 pada sampling kedua, 0,636-1,003 pada sampling ketiga. Menurut Odum (1993), H'< 1 maka keanekaragaman jenis rendah atau perairan kurang subur, untuk H' diantara 1 - 2 maka keanekaragaman jenis sedang atau perairan subur, dan $\mathrm{H}^{\prime}>2$ keanekaragaman jenis tinggi atau perairan sangat subur.

Indeks keseragaman berkisar antara 0,735-0,836 pada sampling pertama, 0,625-0,895 pada sampling kedua, 0,5790,909 pada sampling ketiga. Menurut Krebs (1989) dalam Odum (1993) nilai indeks keseragaman (e) berkisar antara 0 - 1. Jika nilai indeks keseragaman mendekati 0 berarti penyebaran individu tiap spesies tidak sama dan di dalam ekosistem tersebut terdapat kecenderungan terjadinya dominasi spesies yang disebabkan oleh adanya ketidak stabilan faktor - faktor lingkungan maupun populasi. Bila nilai mendekati 1, hal tersebut menunjukkan bahwa ekosistem tersebut berada dalam kondisi relative stabil, yaitu jumlah individu tiap spesies ralatif sama.

Indeks dominasi berkisar antara 0,499-0,624 pada sampling pertama, 0,413-0,619 pada sampling kedua, 0,190-0,554 pada sampling ketiga. Menurut Odum (1993), nilai indeks dominasi berkisaar antara 0 - 1, dimana semakin kecil nilai indeks dominasi maka menunjukan bahwa tidak ada spesies yang mendominasi, sebaliknya semakin besar nilai indeks dominasinya, maka menunjukan bahwa ada dominasi dari spesies tertentu.

Kelimpahan Individu berkisar antara 4275,59-5415,75 individu $/ \mathrm{m}^{3}$ pada sampling pertama, 3705,51-5130,71 individu $/ \mathrm{m}^{3}$ pada sampling kedua, 1995,27-5985,83 individu $/ \mathrm{m}^{3}$ pada sampling ketiga.

Hubungan Tekstur Sedimen dan Bahan Organik dengan makrozoobentos di Habitat Mangrove Pantai Tirang Semarang.

Hubungan fraksi clay dengan kelimpahan makrozoobentos pada Habitat Mangrove Pantai Tirang Semarang terjasi pada gambar 1.

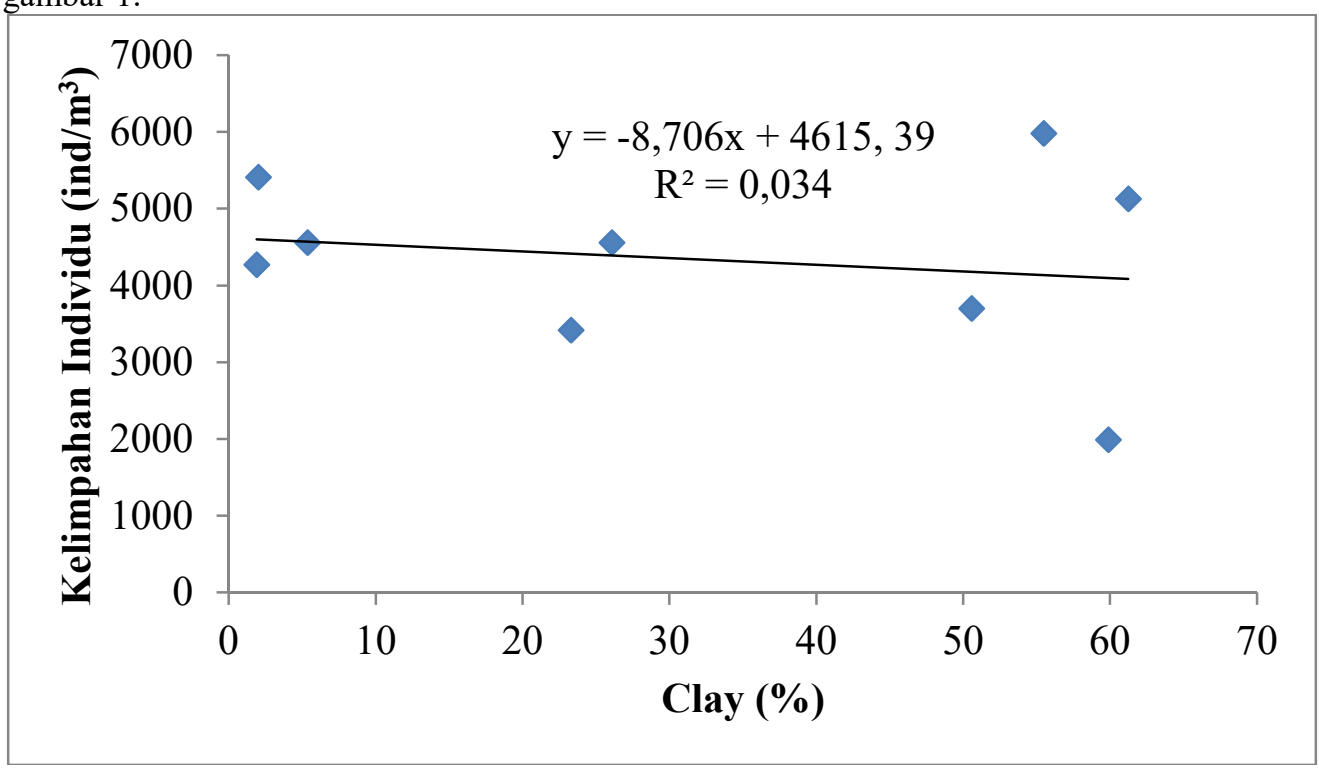

Gambar 1. Hubungan fraksi clay dengan kelimpahan makrozoobentos

Hubungan tekstur sedimen dengan kelimpahan makrozoobenthos dianalisa menggunakan regresi linier. Hasil uji regresi antara tekstur sedimen dengan kelimpahan makrozoobenthos diperoleh nilai koefisien determinasi (R2) sebesar 0,034 yang berarti bahwa 3,4\% tekstur sedimen berpengaruh terhadap kelimpahan makrobenthos dan 96,6\% lagi 
dipengaruhi oleh faktor lain. Koefisien korelasi (r) sebesar -0,18 dengan persamaan regresi y = -8,706x $+4615,39$ yang menunjukkan bahwa hubungan antara kedua variable tersebut memiliki hubungan negatif. Semakin tinggi fraksi clay maka semakin rendah kelimpahan individu. Substrat lumpur dan pasir merupakan habitat yang paling disukai makrozoobentos, selanjutnya Lind (1979) menyatakan bahwa hewan bentos lebih menyenangi dasar perairan dengan substrat lumpur, pasir, kerikil dan substrat sampah. Bentos tidak menyenangi dasar perairan berupa batuan, tetapi jika dasar batuan tersebut memiliki bahan organik yang tinggi, maka habitat tersebut akan kaya akan hewan bentos (Nichol, 1981 dalam Sudarja, 1987). Menurut Nybakken (1992), bahwa tekstur sedimen atau substrat dasar merupakan salah satu faktor ekologis utama yang mempengaruhi kelimpahan dan penyebaran makrozoobenthos. Jenis substrat dasar perairan akan berpengaruh terhadap distribusi dan kelimpahan makrozoobenthos. Tekstur sedimen atau substrat dasar merupakan tempat untuk menempel dan merayap atau berjalan. Susbtrat dasar sebagai penyongkong ketersediaan unsur hara bagi kehidupan makrozoobenthos juga berperan sebagai habitat dan daur hidupnya, sedangkan bahan organik merupakan sumber makananya.

Hubungan bahan organik dengan kelimpahan makrozoobentos pada Habitat Mangrove Pantai Tirang Semarang terjasi pada gambar 2 .

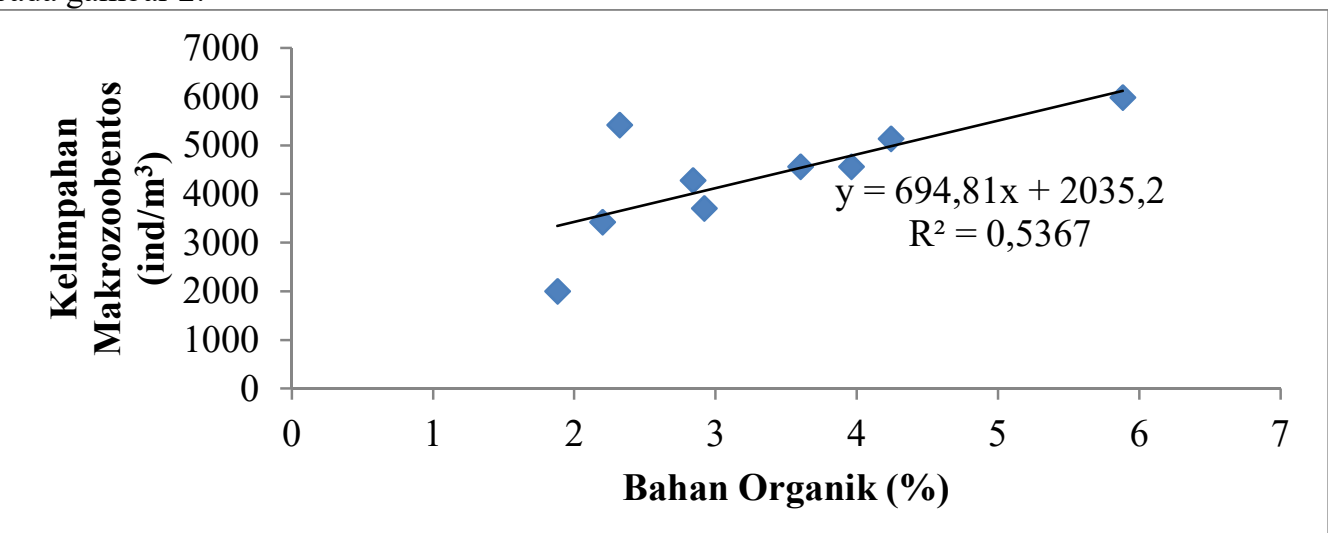

Gambar 2. Hubungan Bahan Organik dengan Kelimpahan Makrozoobentos

Hubungan bahan organik dengan kelimpahan makrozoobenthos dianalisa menggunakan regresi linier. Hasil uji regresi antara bahan organik dengan kelimpahan makrozoobenthos diperoleh nilai koefisien determinasi (R2) sebesar 0,536 yang berarti bahwa 53,6\% bahan organik berpengaruh terhadap kelimpahan makrobenthos dan 46,4\% lagi dipengaruhi oleh faktor lain. Koefisien korelasi (r) sebesar 0,73 dengan persamaan regresi y $=694,8 x+2035,24$ yang menunjukkan bahwa hubungan antara kedua variable memiliki korelasi sedang, semakin tinggi bahan organik maka semakin tinggi kelimpahan makrozoobenthos. Menurut Sugiarto (1992), nilai korelasi (r) =0,5-0,8 berarti keeratan hubungannya sedang. Menurut Nurracmi (2012), makrozoobenthos erat kaitanya dengan tersedianya bahan organik yang terkandung dalam substrat, karena bahan organik merupakan sumber nutrien bagi biota yang pada umunya terdapat pada substrat dasar. Namun jika bahan organik melebihi ambang batas sewajarnya maka kedudukan bahan organik tersebut dianggap sebagai bahan pencemar. Menurut Bengen (2000) bahan organik di perairan terdapat sebagai partikel tersuspensi, bahan organik yang mengalami perubahan dan bahan organik yang berasal dari daratan dan terbawa oleh aliran sungai. Pada umumnya jenis sedimen lumpur lebih kaya akan unsur hara daripada sedimen pasir (Situmorang, 2008).

\section{Kesimpulan}

Kesimpulan yang didapat dari penelitian mengenai Hubungan Tekstur Sedimen dan Bahan Organik dengan makrozoobentos di Habitat Mangrove Pantai Tirang Semarang adalah 1) Tekstur sedimen di dominasi oleh sand (90,9294,56\% sampling pertama) dan clay (26,08-61,24\% sampling kedua, dan 23,28-59,88\% sampling ketiga) dan bahan organik berkisar antara 1,88-5,88\%. 2) Nilai indeks biologi makrozoobentos $\left(\mathrm{H}^{\prime}=0,563-1,003\right.$; e $=0,579-0,909$; $\mathrm{C}=0,371-0,624$ dan $\mathrm{D}=1995,27-5985,83 \mathrm{ind} / \mathrm{m}^{3}$ ). 3) Hubungan tekstur sedimen (fraksi clay) dan bahan organik dengan makrozoobentos. Fraksi clay dengan kelimpahan makrozoobentos memiliki hubungan korelasi terbalik, clay tinggi kelimpahan makrozoobentosnya rendah dan koefisien korelasinya -0,18. Bahan organik dengan kelimpahan makrozoobentos memiliki hubungan korelasi sedang, bahan organik tinggi kelimpahan makrozoobentosnya tinggi dan koefisien korelasinya 0,73 .

\section{Ucapan Terima Kasih}

Penulis mengucapkan terima kasih kepada, Churun Ain, S.Pi, M.Si. yang telah memberikan saran untuk perbaikan artikel ini dan teman saya Ahmad Fuad dan Donal Siahaan yang telah membantu dalam pengambilan sampel di Habitat Mangrove Pantai Tirang. 


\section{DAFTAR PUSTAKA}

Bengen, D.G., 2001. "Pedoman Teknis Pengenalan dan Pengelolaan Ekosistem Mangrove, Pusat Kajian Sumberdaya Pesisir dan Lautan". Institut Pertanian Bogor. Bogor. Indonesia.

Effendie, H. 2003. Telaah Kualitas Air. Bagi Pengelolaan Sumberdaya dan Lingkungan Perairan. IPB. Bogor.

Hutabarat,S., dan Stewart.M.Evans., 2000. Pengantar Oseanografi, Universitas Indonesia-Press, Jakarta.

Ihklas. 2001. Struktur Komunitas Makrozoobentos Pada Ekosistem Hutan Mangrove di Pulau Sarapa Kecamatan Liukang Tupabiring Kabupaten Pangkep. Sulawesi Selatan. Universitas Hassanuddin. Makassar

Krebs, C. J. 1985. Ecology. The Experimental Analysis of Distribution and Abundance. Harper and Row Publication. New York.

Lind, O.T. 1979. Handbook of common Method in Limnology. The C.V. Mosby Company. St. Louis, Missouri. 199 hlm.

Mardi. 2014. "Keterkaitan Struktur Vegetasi Mangrove Dengan Keasaman dan Bahan Organik Total Sedimen Pada Kawasan Suaka Margasatwa Mampie di Kecamatan Wonomulyo Kabupaten Polewali”. Universitas Hasanuddin. Makassar.

Mukminin. A. 2009. Proses Sedimentasi di perairan pantai Dompak Kecamatan Bukit Bestari Provinsi Kepulauan Riau. Universitas Riau 2009.

Nontji, A. 1993. Laut Nusantara. Penerbit Djambatan. Jakarta.

Nurrachmi, I. dan Marwan. 2012. Kandungan Bahan Organik Sedimen dan Kelimpahan Makrozoobenthos sebagai Indikator Pencemaran Perairan Pantai Tanjung Uban Kepulauan Riau. LIPI Universitas Riau. Pekanbaru

Nyabakken, J.W. 1988. Biologi Laut Suatu Pendekatan Ekologi. P.T. Gramedia. Jakarta.

1992. Biologi Laut Suatu Pendekatan Ekologis. Diterjemahkan Oleh Eidman dan Bengen. PT. Gramedia Jakarta.

Odum, E. P. 1971. Fundamental of Ekology. Third Edition, W.B. Saunders Company. Toronto Florida.

1993. Dasar-dasar Ekologi. Edisi Ketiga. Diterjemahkan oleh T. Samingan. Gadjah Mada University Press. Yogyakarta. 697 hal.

Rahman, F.A. 2009. Struktur Komunitas Makrozoobenthos di Perairan Estuaria Sungai Brantas (Sungai Porong dan Wonokromo), Jawa Timur. IPB. Bogor.

Roswaty, M. R. Muskananfola dan P. W. Purnomo. 2014. Tingkat Sedimentasi Di Muara Sungai Wudung Kecamatan Wedung, Demak. Maquares 3(2): 129-137.

Situmorang, S. P. 2008. Geokimia Pb, Cr, Cu dalam Sedimen dan Ketersediaannya pada Biota Benthik di Perairan Delta Berau, Kalimantan Timur. Skripsi. Departemen Ilmu dan Teknologi Kelautan. Fakultas Perikanan dan Ilmu Kelautan. Institut Pertanian Bogor. Bogor. 100 hal.

Sugiarto. 1992. Tahap Awal Dan Aplikasi Analisis Regresi. penerbit Andi Offset. Yogyakarta.

Syamsurisal. 2011. "Studi Beberapa Indeks Komunitas Makrozoobenthos di Hutan Mangrove Kelurahan Coppo Kabupaten Barru". Universitas Hasanuddin. Makassar.

Zahidin, M. 2008. Kajian Kualitas Air di Muara Sungai Pekalongan Ditinjau dari Indeks Keanekaragaman Makrobenthos dan Indeks Saprobitas Plankton. Universitas Diponegoro. Semarang. 